\title{
Como normas constitucionais não escritas mudam Constituições escritas ${ }^{1}$
}

\author{
Richard Albert \\ Professor Associado de Direito Constitucional em Boston College Law School. Doutor em \\ Direito e Graduado por Yale University. Graduado em Direito Civil por Oxford University. \\ Mestre em Direito por Harvard University. E-mail: richard.albert@bc.edu \\ Tradução de Matheus Henrique dos Santos da Escossia \\ Mestrando em Direito Público pela Universidade do Estado do Rio de Janeiro (UERJ). \\ Graduado em Direito pela Faculdade de Direito de Vitória (FDV/ES). Advogado. E-mail: \\ matheushsescossia@gmail.com
}

\section{Resumo}

Constituições escritas são suscetíveis a mudanças informais que não se manifestam propriamente em alterações do texto, por exemplo, como resultado de interpretação judicial, proposição legislativa ou ação do Executivo. Esse fenômeno é bem desenvolvido na literatura acadêmica sobre mudança constitucional e emenda constitucional informal. Mas o que permanece sem estudo e sem teorização no Canadá e nos Estados Unidos é como constituições escritas mudam informalmente como um resultado do desenvolvimento de uma norma constitucional não escrita, também chamado de costume constitucional $^{2}$. Nesse artigo, minha hipótese com referência às Constituições do Canadá e dos Estados Unidos é que existem duas categorias principais de mudança constitucional informal por costume constitucional: Incorporação e Negação. Eu sugiro também que a incorporação e o negação talvez ocorram de duas formas: incorporação talvez ocorra por preenchimento de um vazio no texto constitucional ou por refinamento de alguma de suas previsões já existentes, e negação talvez resulte a partir da criação de um vazio no texto constitucional ou por substituição de um vazio já existente. Daí eu avalio se essas quatro formas de mudança constitucional informal por costume constitucional geram custos ao estado de direito onde o significado constitucional é enraizado no debate público presente acerca do texto constitucional. Meu maior propósito nesse artigo é convidar ao diálogo com acadêmicos de direito público comparado sobre como normas constitucionais não escritas mudam constituições escritas o que pode, em última análise, significar um melhor entendimento das formas e implicações das mudanças constitucionais não escritas.

1 Originalmente publicado com o título How unwritten constitutional norms change written constitutions, Dublin University Law Journal, v. 38, n. 2, 2015.

2 NT. Do original "constitutional convention". 
Palavras-chave

Costume Constitucional, Interpretação, Normas Constitucionais, Emendas.

\title{
How unwritten constitutional norms change written constitutions
}

\begin{abstract}
Written constitutions are susceptible to informal changes that do not manifest themselves in alterations to the text, for instance as a result of judicial interpretation, legislative enactment or executive action. This phenomenon is well developed in the scholarly literature on constitutional change and informal constitutional amendment. But what remains understudied and undertheorized in Canada and the United States is how written constitutions change informally as a result of the development of an unwritten constitutional norm, otherwise known as a constitutional convention. In this Article, I hypothesize with reference to the Canadian and United States Constitutions that there exist two major categories of informal constitutional change by constitutional convention: incorporation and repudiation. I suggest also that incorporation and repudiation may each occur in two ways: incorporation may occur by filling an existing void in the constitutional text or by refining one of its existing provisions, and repudiation may result from creating a void in the constitutional text or from substituting one of its existing provisions. I then evaluate whether these four forms informal constitutional change by constitutional convention entail costs to the rule of law where constitutional meaning is rooted in the present public meaning of the constitutional text. My larger purpose in this Article is to invite a dialogue with comparative public law scholars on how unwritten constitutional norms change written constitutions so that we may ultimately better understand the forms and implications of unwritten constitutional change.
\end{abstract}

\section{Keywords}

Constitutional Convention, Interpretation, Constitutional Norms, Amendments.

\section{Sumário}

1. Introdução; 2. Mudança Constitucional Informal por Incorporação; A. Incorporação por preenchimento de vazio; B. Incorporação por refinamento; 3. Mudança Constitucional Informal por Negação; A. Negação por criação de um vazio; B. Negação por substituição; 4. Mudança Constitucional Informal e o Estado de Direito; A. A Congruência entre Texto Constitucional e Prática Política; B. Mudança Constitucional Informal por Costume Constitucional; 5. Conclusão

\section{Introdução}

Constituições codificadas, às quais eu vou referir nesse artigo como constituições escritas $^{3}$, comumente estabelecem regras formais de reforma que autorizam atores

${ }^{3}$ A textualidade falha em distinguir a Constituição dos Estados Unidos da Constituição Britânica, por exemplo, porque todas as Constituições são escritas de alguma forma. Conferir Michael Fonley, $O$ 
políticos mudar o texto constitucional em conformidade com procedimentos especiais ${ }^{4}$. Regras formais de emenda, por exemplo, requerem que o Poder de Reforma reúna uma aprovação supermajoritária na legislatura ${ }^{5}$, uma aprovação majoritária entre os eleitores ${ }^{6}$, ou talvez requeira uma combinação entre essas duas ${ }^{7}$. Constituições escritas talvez também estabeleçam restrições em razão da matéria que proíbe emendar determinados valores constitucionais ${ }^{8}$, talvez imponham limitações temporais que forçam ou constrangem o tempo e a duração do processo de emenda constitucional ${ }^{9}$, e eles também talvez impeçam o procedimento formal de emenda em tempos de crises $^{10}$. Regras formais de emenda, consequentemente, providenciam um roteiro de como e quando emendar o texto constitucional, quem está apto a propor emendas, quando a emenda deve se iniciar e ser ratificada, além da extensão do texto que é emendável.

Constituições escritas talvez também mudem informalmente. Uma mudança informal ocorre onde o significado concretizável da constituição muda sem que se altere o texto constitucional ${ }^{11}$. Por exemplo, onde uma corte possui o poder de revisão judicial de constitucionalidade ${ }^{12}$ e onde esse poder é efetivo, a força vinculante da corte nacional

silêncio das Constituições: lacunas, 'pendências' e temperamento político na manutenção do governo (Routledge, 2013) (explorando as funções e limites da textualidade). A real distinção é codificação: a Constituição dos Estados Unidos é codificada em uma Constituição única, enquanto a Constituição Britânica existe em uma forma escrita, porém esparsa.

${ }^{4}$ Bjørn Erik Rasch \& Roger D. Congleton, 'Amendment Procedures and Constitutional Stability' in Roger D.Congleton \& Birgitta Swedenborg (eds), Democratic Constitutional Design and Public Policy MIT Press, 2006. p. 325.

${ }^{5}$ Ver, por exemplo, Constituição do Chile, capítulo XV, arts. 127-29 (1980); Constituição da Noruega, parte E, art. 112 (1814); Constituição dos Estados Unidos, art. V (1789).

${ }^{6}$ Ver, por exemplo, Constituição da Estônia, capítulo XV, seção 162 (1992); Constituição da Irlanda, art. 46(2) (1937); Constituição da Suíça, título VI, capítulo 1, arts.192-95 (1999).

7 Ver, por exemplo, Constituição da Austrália, capítulo VIII, art. 128 (1900); Constituição do Japão, capítulo IX, art. 96 (1947); Constituição de Maurício, capítulo V, parte II, art. 47(3) (1958).

8 Ver, por exemplo, Constituição da França, título XVI, art. 89 (1958) (proibindo emendas ao republicanismo); Constituição da Alemanha, parte VII, art. 79(3) (1949) (proibindo emendas ao federalismo); Constituição de Portugal, parte IV, título II, art. 288(c) (1976) (proibindo emendas ao secularismo).

${ }_{9}^{9}$ Ver, por exemplo, Constituição de Cabo Verde, parte VI, título III, art. 309(1) (1980) (proibindo emenda durante um período de cinco anos após sua entrada em vigor); Constituição da Costa Rica, título XVII, art. 195(3) (1949) (estabelecendo um máximo de período para a Comissão deliberar uma proposta de emenda); Constituição da Coreia do Sul, capítulo X, art. 129 (1948) (requerendo um período de tempo mínimo para deliberar sobre uma proposta de emenda).

10 Ver, por exemplo, Constituição da Bélgica, título VIII, art. 196 (1994) (impedindo regras de emenda constitucional durante estado de emergência, lei marcial, estado de sítio ou guerra); Constituição de Luxemburgo, capítulo XI, art. 115 (1868) (proibindo emenda durante regência); Constituição da Espanha, parte V, art. 116 (1978) (restringindo emenda durante guerra, estado de sítio ou estado de emergência).

11 Heather K. Gerken, 'The Hydraulics of Constitutional Reform: A Skeptical Response to Our Undemocratic Constitution'. Drake Law Review,v. 55, 2007, p. 925-929.

12 Isso se aplica também em democracias constitucionais com uma forma fraca de controle de constitucionalidade, onde mecanismos legislativos ou populares criados para confirmar as decisões

Revista Publicum

Rio de Janeiro, v.2, n. 2, 2016, p. 9-44

http://www.e-publicacoes.uerj.br/index.php/publicum

DOI: 10.12957/publicum.2016.27017 
como último recurso para a interpretação do texto constitucional se aproxima qualitativamente de uma emenda constitucional escrita ${ }^{13}$. A forma de entrincheiramento talvez difira seus efeitos, mas eles são indistinguíveis ${ }^{14}$. Essa é a maneira pela qual uma constituição escrita talvez seja alterada informalmente. Interpretação judicial é apenas um único método. Existem outros, incluindo proposição legislativa e ação executiva ${ }^{15}$.

Não é inabitual que constituições escritas mudem informalmente. Mesmo nos Estados Unidos, o modelo de democracia constitucional com um texto codificado, não se deve ler a constituição como uma lista exaustiva de comandos, deveres, procedimentos, direitos e alocações de poder. Claro que muito do que nós entendemos como Constituição existe nos quatro cantos do texto. O falecido Felix Frankfurter, antigo Justice da Suprema Corte americana, consequentemente impreciso em várias coisas, mas sobretudo sobre o significado formal da Constituição ao assumir que "nada novo pode ser colocado na Constituição exceto pelo processo de emenda. Nada velho pode ser retirado sem seguir o mesmo processo"16. O estudo da mudança constitucional simplesmente não pode escapar da realidade das Constituições nem sempre estão completamente escritas, nem em um único lugar, nem em sua inteireza ${ }^{17}$.

Apesar do crescente corpo de acadêmicos sobre mudança constitucional informal, o que há muito tem recebido pouca atenção no Canadá e nos Estados Unidos é como normas constitucionais não escritas interagem com constituições escritas e de vez em quando informalmente alteram-nas ${ }^{18}$. Hans Kelsen aludiu à inevitabilidade dessas mudanças informais quando ele insistia que "não existe possibilidade legal de prevenir a constituição de ser modificada por costume, mesmo se a constituição possui a característica de direito estatutário, ainda assim é também chamada de constituição

das Cortes não são usados. Ver Mark Tushnet, Weak Courts, Strong Rights: Judicial Review and Social Welfare Rights in Comparative Constitutional Law. Princeton University Press, 2009. p. 61.

${ }^{13}$ Ver Tom Ginsburg \& Eric A. Posner, 'Subconstitutionalism'. Stanford Law Review, v. 62, 2010. p. 1583-1600.

${ }^{14}$ Mark Tushnet, 'Progressive Constitutionalism: What is "it”?'. Ohio State Law Journal, v. 72, 2011. p. 1073-1080.

${ }^{15}$ Ver Bruce Ackerman, We the People: Transformations. Harvard University Press, 1998. p. 15-26; S.N. Ray, Modern Comparative Politics: Approaches, Methods and Issues. 3a ed. Prentice-Hall, 2004. p. 117-31; Jeremy Webber, Reimagining Canada: Language, Culture, Community, and the Canadian Constitution. McGill-Queen's UniversityPress, 1994. p. 260-305; Richard Albert, 'Constitutional Disuse or Desuetude: The Case of Article V'. Boston Univeristy Law Review, v. 94, 2014. p. 1029, 1060-71.

${ }^{16}$ Ullmann v United States, 350 US 422, 428 (1955).

${ }^{17}$ Anthony King, The British Constitution. Oxford University Press, 2007. p. 5.

${ }_{18}$ Algumas lições acadêmicas que são úteis nesse ponto são: Akhil Reed Amar, America's Unwritten Constitution: The Precedents and Principles We Live By. Basic Books, 2012. p. xii; James Ross Hurley, Amending Canada's Constitution: History, Processes, Problems and Prospects. Ministry of Supply and Services Canada, 1996. p. 14-16; Keith E. Whittington, 'The Status of Unwritten Constitutional Conventions in the United States'. U III L Rev, 2013. p. 101-102.

Revista Publicum

Rio de Janeiro, v.2, n. 2, 2016, p. 9-44

http://www.e-publicacoes.uerj.br/index.php/publicum

DOI: 10.12957/publicum.2016.27017 
'escrita'19". O que Kelsen referia como costume é o que entendemos como costume constitucional, uma regra que cria uma obrigação, confere direitos ou poderes, ou, de outra forma, governa a conduta de atores políticos.

Um costume constitucional se desenvolve, como Ivor Jennings explicou, onde existem precedentes, onde atores políticos se sentem vinculados pelo precedente e onde existe razão para respeitar o precedente ${ }^{20}$. A chave para Jennings testar e verificar a existência do costume constitucional é o que atores políticos pensam, sentem e eventualmente fazem. Um costume talvez seja dito existir apenas onde nós percebamos e identificamos mais que a "mera prática"21; isso requer que atores políticos conformem suas condutas à prática porque eles "acreditam que devem fazê-lo"22. Autopercepção, daí, é a chave para a formação do costume. Uma prática, para se tornar costume, deve também ser enraizada com normatividade. Ela deve "autorizar [...] a maquinaria do Estado agir mais suavemente" e ela deve ser "desejável nas circunstâncias da Constituição"23.

Em democracias constitucionais com texto codificado, costumes criam uma regra que obriga atores políticos agirem de uma forma que não é exigida a partir do texto constitucional. Com isso, nós devemos olhar para fora do texto constitucional para identificar costumes constitucionais. Eles são conhecidos por conduzir outros enquanto eles refletem "ultimamente refletem o que o povo faz" ${ }^{24}$. Costumes, consequentemente, nem sempre criam descontinuidade de gravitação variável entre texto e prática. 0 mais grave ocorre onde um costume cria uma regra obrigando atores políticos agirem "de um modo diverso do que o direito formal prescreve ou autoriza" ${ }^{25}$. Nesse caso de sério descompasso entre texto constitucional e conduta oficial, a consequência é problemática para o verdadeiro propósito da textualidade porque o costume aparece em lugar algum no texto e o conflito entre o texto escrito e o costume como praticado parece subordinar o texto à convenção.

Costumes constitucionais podem modificar o significado, embora não o texto formal, de constituições escritas. Minha hipótese está em dois métodos principais. Primeiro, um costume talvez incorpore algo novo no texto da constituição sem resultar

19 Hans Kelsen, General Theory of Law and State. Trad. Anders Wedberg. Harvard University Press, 1945. p. 259.

${ }^{20}$ Ivor Jennings, The Law and The Constitution. 5a edição. University of London Press,1967. p. 136.

$21 \mathrm{lbid}$, p. 134.

$22 \mathrm{lbid}, \mathrm{p} .135$.

$23 \mathrm{lbid}$, p. 136.

${ }^{24}$ Geoffrey Marshall, Constitutional Conventions: The Rules and Forms of Political Accountability. Oxford University Press, 1984. p. 217.

${ }^{25}$ Andrew Heard, Canadian Constitutional Conventions: The Marriage of Law and Politics. 2a edição. Oxford University Press, 2013. p. 5.

Revista Publicum 
em uma nova escrita. Segundo, um costume pode fazer o oposto: ele pode informalmente rejeitar, ainda que não formalmente repila, algo que é correntemente escrito no texto. Cada um desses dois métodos principais se manifestam em duas maneiras. Incorporação talvez ocorra ao preencher um vazio existente no texto constitucional, onde a importância do conteúdo do costume que preenche o vazio não é presentemente endereçada no texto. Incorporação talvez também ocorra por refinamento onde a importância do conteúdo do costume o que refina o texto constitucional existente é de alguma forma já endereçado no texto. Negação, por outro lado, talvez ocorra em duas maneiras. Negação pode ocorrer onde um costume cria um vazio no texto constitucional ao efetivamente impedir provisões entrincheiradas no texto constitucional. Negação talvez também ocorra por substituição onde um costume abertamente contradiz uma constituição escrita. Cada um desses quatro tipos de mudança informal implica seus próprios custos para os valores do estado democrático de direito a serviço de uma constituição escrita, quais sejam previsibilidade, transparência e prestação de contas.

É importante admitir no início que esses pares de distinção - preenchimento de vazio e refinamento; criação de vazio e substituição - são intencionados para ser explanatórios, porém não definitivos. Eu apresento eles como hipóteses sobre como costumes constitucionais podem mudar constituições escritas. Alguém poderia plausivelmente suscitar que existem apenas duas grandes formas de mudança informal por costume constitucional - incorporação e negação - porque qualquer distinção mais específica que essa é muito tênue para resistir ao escrutínio. Alguém poderia alternativamente argumentar que existe apenas uma única forma de mudança informal por costume constitucional - mudança propriamente dita - e que qualquer outra distinção é, no melhor cenário, forçada. Por exemplo, alguém poderia suscitar que a incorporação do novo costume constitucional implica negação do costume existente na extensão dos conflitos com um novo, assim como alguém poderia implicar a negação de um costume constitucional existente resulta na incorporação do novo costume na constituição.

As categorias que eu escolhi são, consequentemente, contestáveis. Apesar disso, ao contestar essas categorias e seus limites exteriores que nós clarearemos as comparações relevantes, continuidades e descontinuidades que talvez façam essas características ou outras categorias analiticamente úteis. Minha abordagem aqui é reducionista: examinar mudanças informais por costume constitucional no seu nível mais baixo de abstração. Minha proposta imediata é daí avaliar os custos da mudança informal por costume ao estado de direito. Embora eu ofereça ilustrações para cada uma dessas

Revista Publicum 
quatro formas de mudança informal por costume convencional, eu estou menos preocupado em persuadir leitores que cada exemplo particular que escolhi é ilustrativo da categoria de mudança informal classificada que estabelecer hipóteses de cada uma dessas quatro categorias que existem e implicar diferentes consequências para os valores democráticos do estado de direito. Os custos do estado de direito irão variar de acordo com a constituição escrita estar sendo informalmente modificada como um resultado de preenchimento de vazio, refinamento, criação de um vazio ou substituição. Minha proposta principal nesse artigo é melhor compreender a inter-relação entre textualidade e costumes, um assunto sub-explorado no Canadá e nos Estados Unidos, e engajar acadêmicos de direito público comparado no diálogo sobre formas e implicações de mudança constitucional informal em democracias constitucionais onde o texto importa.

Eu assumo uma abordagem modesta nessa pergunta da relação entre textualidade e costumes e eu também reconheço os limites inerentes no empreendimento comparativo. Seria difícil sustentar e, claro, seria inoportuno em fazer, a sugestão de que todos as constituições democráticas interajam com costumes constitucionais em apenas quatro modos. Primeiro, costumes são tratados de maneira diferente entre as jurisdições e, claro, exercem diferentes efeitos legais de uma tradição constitucional para outra. Em uma jurisdição, talvez seja judicialmente reconhecível mas não justiciável, e em outra talvez seja entendida como fonte de direito que requeiram interpretação judicial e aplicação ${ }^{26}$. Além disso, existem desafios na definição e na linguagem em apontar precisamente o que chamamos de "costume" quando o termo é usado entre jurisdições: algumas tradições constitucionais usam o termo "costume" e "convenção" de modo intercambiáveis, outras usam o termo "costume" e não "convenção", e outras distinguem um do outro ${ }^{27}$. O ponto é que abordagens comparativas, na medida do possível, não deveriam aparecer compreensivas onde o terreno coberto é menor, seja como resultado de barreiras linguísticas, diferenças constitucionais e, claro, por inabilidade de levar em conta todas as diferenças entre as especificidades jurisdicionais. Isso porque, nesse artigo, minha abordagem é apresentar uma hipótese que os acadêmicos do direito público comparado podem ajudar a verificar, melhorar, desafiar ou rejeitar, enquanto nós coletivamente nos aprofundamos nosso entendimento de mudança constitucional.

Eu começo, na Parte II e III, em explicar e ilustrar com referência às Constituições do Canadá e dos Estados Unidos como costumes constitucionais modificam constituições escritas. Parte II explora os dois métodos subsidiários de incorporação enquanto Parte III

${ }^{26}$ Esse importante ponto emergiu de um produtivo e estimulante colóquio com Tania Groppi.

$27 \mathrm{Ibid}$. 
explora os dois métodos subsidiários de negação. Na Parte IV, eu sugiro que todos menos uma das quatro categorias de mudança informal por costume constitucional são problemáticas para os valores do estado democrático de direito em regimes constitucionais baseados no texto. Eu fecho a parte $\mathrm{V}$ com reflexões na relação entre textualidade e mudança constitucional em democracias que são baseadas no texto constitucional.

\section{Mudança Constitucional Informal}

Em regimes democráticos sem uma constituição textual, mudança constitucional geralmente ocorre, embora não exclusivamente, através de adoção, adaptação e erosão de costumes constitucionais ${ }^{28}$. Essas Constituições não escritas mudam por evolução nos tácitos entendimentos do direito e da política, sustentados pelos governantes e aceitos pelos governados ${ }^{29}$. Mudança informal por costume, assim, parte de regras estritamente legais que nós associamos com mudança constitucional em regimes com constituições ${ }^{30}$ textuais, onde atores políticos talvez alterem o texto constitucional a partir de implantação de um procedimento formal requerendo regras especiais de acordo ${ }^{31}$.

Costumes constitucionais também podem alterar constituições escritas, embora apenas informalmente, a partir da criação, retardo ou aceleração da mudança constitucional, todas sem a alteração do texto. Em um regime textual, o que resulta de um informal entrincheiramento do costume constitucional é um novo significado constitucional sem uma nova constituição escrita. Existem dois grandes caminhos pelos quais os costumes constitucionais podem alterar constituições escritas: por incorporação de algo novo no texto e negação a algo contrário. Na próxima Parte, eu vou mostrar dois meios sutis semelhantes em que os costumes podem mudar a constituição por negação. É válido fazer distinções entre essas quatro formas de mudança constitucional porque cada uma gera consequências diferentes ao estado de direito, como eu vou discutir na Parte IV.

Constituições escritas podem ser bem específicas no seu conteúdo. Por exemplo, a Constituição holandesa exige que o parlamento regule o acesso público de encontros que se deem em águas locais ${ }^{32}$. A Constituição venezuelana indica que os municípios devem manter procedimentos para multas e penalidades que eles impuserem dentro de sua

\footnotetext{
${ }^{28}$ Ver Marshall, nota supra 22,8.

${ }^{29}$ Ver S.E. Finer et al, Comparing Constitutions. Clarendon Press, 1995. p. 100.

30 Ver Marshall, supra note 22, p. 216-17.

31 Ver Francesco Giovannoni, 'Amendment Rules in Constitutions' Public Choice, v. 115, 2003. p. 37.

32 Constituição da Holanda, cap. VII, art. 133 (1983).
} 
autoridade jurisdicional, bem como taxas administrativas para questões como licenciamento ${ }^{33}$. A Constituição mexicana específica que o Instituto Federal Eleitoral deve dar 48 minutos de cobertura de rádio e de televisão cada dia durante uma eleição ${ }^{34}$. Esse modelo de operações manuais de especificidades constitucionais contrasta com a Constituição dos Estados Unidos, que é escrita em amplos rabiscos de um quadro de generalidade constitucional ${ }^{35}$, embora seu curso também prescreve algumas questões bem detalhadas ${ }^{36}$.

Mas mesmo as constituições codificadas mais específicas são incompletas. Elas não podem, tampouco conseguiriam, refletir por completo o direito em nível constitucional. Existem muitas razões para tanto: algumas legislações talvez se tornem tão importantes que passem a adquirir um status quase constitucional ${ }^{37}$; regras e normas extra-canônicas, como regulações e práticas administrativas, em que pese não entrincheiradas, talvez formem parte da "Constituição fora da Constituição" 38 , e, claro, costumes constitucionais surgindo da prática política talvez cresçam para exercer tanto constrangimento ou empurrar força aos atores políticos quanto efetivamente uma regra constitucional faria. Essa terceira razão é uma das formas que foco no presente Artigo. Eu começo com a proposição de que "a partir de que uma constituição seja forjada, daí quase que inevitavelmente costumes vão surgir para suplementar e pôr em efeitos práticos as expressas provisões das constituições escritas"39. A abstenção desses costumes descodificados de uma constituição escrita consequentemente concebe como a constituição realmente funciona.

\section{A. Incorporação por preenchimento de vazio}

A missão, então, é mostrar como um costume constitucional "surgirá para suplementar"40 a constituição escrita. Aqui, eu coloco dois métodos com os quais um costume pode surgir para suplementar a constituição escrita de um modo que "transforma o efeito prático em

\footnotetext{
33 Constituição da Venezuela, Título IV, cap. IV, art. 179 (1999).

${ }^{34}$ Constituição do México, Título II, cap. I, art. 41(III) (1917).

35 Ver Jack M. Balkin, 'The Framework Model and Constitutional Interpretation' (April 14, 2015) at 3 <http://ssrn.com/abstract=2607105> acessado 01ㅇ de junho de 2015 (distinguindo o arranha-céu do modelo de Constituições escritas).

${ }^{36}$ A generalidade desse modelo talvez tenha contribuído para que a Constituição dos Estados Unidos tenha durado mais de 200 anos. Ver Zachary Elkins et al, The Endurance of National Constitutions. Cambridge University Press, 2009. p. 84.

37 Ver William N. Eskridge, Jr., \& John Ferejohn, 'Super-Statutes'. Duke LJ, v. 50, 2001. p. 1215, 121617.

${ }^{38}$ Ver Ernest A. Young, 'The Constitution Outside the Constitution'. Yale LJ, v. 117, 2007. p. 408-415.

${ }^{39}$ G. Maher, 'Custom and Constitutions'. Oxford J Leg Stud, v. 1, 1981. p. 167-171.

$40 \mathrm{lbid}$.
} 
provisão expressa"41. Um meio é por adição completa: um costume pode suplementar a constituição escrita onde o conteúdo do costume não já está endereçado no texto constitucional, assim preenchendo um vazio no texto constitucional existente.

Um exemplo útil de incorporação por preenchimento de vazio é costume de dois mandatos presidenciais nos Estados Unidos. Quando a Constituição dos Estados Unidos entrou em vigor em 1789, ela foi silenciosa sobre a questão da reeleição e elegibilidade presidencial, além de não ter assinalado no texto ou em sua ampla arquitetura se um presidente deveria ou não deveria ter mais de um mandato. A Constituição estabeleceu apenas que a "duração do mandato presidencial será de quatro anos" ${ }^{42}$, sem dizer mais. Os presidentes, assim, poderiam deter um número ilimitado de mandatos, se devidamente eleitos, preenchendo as condições constitucionais de elegibilidade presidencial, que incluem os requisitos de cidadania, idade e residência ${ }^{43}$.

O silêncio da Constituição sobre a reelegibilidade e reeleição presidenciais não passaram desapercebidas, nem foram incontroversas, como legisladores introduziram aproximadamente 300 resoluções entre 1789 e 1947 para estabelecer limites ao mandato presidencial ${ }^{44}$. Eventualmente em 1951, atores políticos emendaram a Constituição para formalmente estabelecerem o limite de dois mandatos na 22a Emenda ${ }^{45}$.

Nós podemos traçar as origens da 22a Emenda a partir do primeiro presidente, George Washington, que se afastou da presidência em 1796 depois de ter apenas dois mandatos consecutivos, apesar das probabilidades de que ele teria ganho uma terceira eleição presidencial ${ }^{46}$. A recusa de Washington para se lançar a um terceiro mandato não estabeleceu por si só a tradição dos dois mandatos ${ }^{47}$, embora ao tempo do fim do segundo mandato essa escolha estabeleceu o que um acadêmico se referiu como "quase direito não escrito", virtualmente tão sagrada quanto qualquer provisão da Constituição ${ }^{48}$. Como os sucessores de Washington seguiram seu exemplo ${ }^{49}$, eles fortemente

\footnotetext{
${ }^{41} \mathrm{lbid}$.

42 Constituição dos Estados Unidos, art. II, seção 1(1).

43 Ibid art. II, seçãp 1(5).

${ }^{44}$ Ver Paul G. Willis \& George L. Willis, 'The Politics of the Twenty-Second Amendment'. W Pol Q, v. 5, 1952. p. 469.

45 Constituição dos Estados Unidos, emenda XXII.

${ }^{46}$ See Richard Albert, 'The Evolving Vice Presidency'. Temple L Ver, v. 78, 2005. p. 811, 853-854.

47 Claro que Washington não quis vincular seus sucessores a seguir o exemplo dele de não servir mais que dos mandatos presidenciais. Ver Bruce G. Peabody \& Scott E. Gant, 'The Twice and Future President: Constitutional Interstices and the Twenty-Second Amendment'. Minn L Ver, v. 83, 1999. p. 565-577.

48 Ver Stephen W. Stathis, 'The Twenty Second Amendment: A Practical Remedy or Partisan Maneuver'. Const Comment, v. 7, 1990. p. 61-63.

49 É importante sublinhar aqui que um costume não era apenas o presidente não se lançar a um terceiro mandato. É o fato de que o presidente não irá buscar um terceiro mandato eletivo
} 
entrincheiraram um modelo de dois mandatos que, em 1875, a Câmara dos Deputados ${ }^{50}$ passaram uma resolução reconhecendo que o "precedente estabelecido por Washington e outros presidentes dos Estados Unidos, que não podem se reeleger após o segundo mandato, se tornou, por um acordo universal, a parte de nosso sistema republicano de governo" ${ }^{51}$.

O costume dos dois mandatos ajuda a ilustrar o preenchimento do vazio. O silêncio da Constituição sobre reeleição e elegibilidade presidencial criou espaço para o costume se enraizar. Não existe obrigação constitucional peremptória requerendo que presidentes contestem ou rejeitem uma segunda reeleição. Isso permitiu atores políticos, no caso Washington e seus sucessores imediatos, a discricionariedade de escolher se lançar ou não para um terceiro mandato presidencial consecutivo. Atores políticos subsequentes tiveram a oportunidade de repetir, modificar ou completamente suspender a tradição de dois mandatos. Mas ao longo do tempo, com os sucessivos presidentes começando a seguir o modelo de Washington, a tradição de dois mandatos se amadureceu em um costume, cujos efeitos cresceram para assemelhar o que nós esperamos de uma regra constitucional textualmente entrincheirada. O limite de dois mandatos assim deve ser visto como um crescimento de um costume constitucional bem antes de ser entrincheirado no texto constitucional.

\section{B. Incorporação por refinamento}

Além da incorporação por preenchimento de vazio, existe um segundo modo de que um costume constitucional "surgirá para complementar" a constituição escrita para "pôr em efeito prático suas provisões expressas" ${ }^{52}$. Um costume constitucional talvez também possa ser incorporado à constituição por refinamento. Em contraste ao preenchimento do vazio - onde o conteúdo da mudança constitucional não é rapidamente endereçado no texto constitucional - refinamento ocorre onde o conteúdo da mudança constitucional é tão logo endereçada nele. Ao refinar o texto, o costume traz novos elementos ou especifica algo novo sobre nosso entendimento das palavras existentes, embora em nenhum caso o refinamento crie uma inconsistência com a leitura plena do texto.

consecutivo ou subsequente, salvo se existir uma emergência exigindo a continuidade na presidência. Ver Joseph Jaconelli, 'The Nature of Constitutional Convention'. Leg Stud, v. 19, 1999. p. 24-33.

50 NT: House of Representatives

51 Stathis, supra, p. 46, 64.

52 Maher, supra, p. 37, 171.

Revista Publicum

Rio de Janeiro, v.2, n. 2, 2016, p. 9-44

http://www.e-publicacoes.uerj.br/index.php/publicum

DOI: $10.12957 /$ publicum.2016.27017 
Considere um exemplo que contrasta com o preenchimento do vazio. No Canadá, a norma do consentimento das províncias sobre emendas constitucionais de questões de alto relevo é um exemplo de costume se enraizando onde o conteúdo já havia sido endereçado no texto constitucional. Antes de adotar essa estrutura escalonada das regras formais de emenda no Constitutional Act, em $1982^{53}$, a Constituição poderia ser formalmente emendada apenas pelo Parlamento do Reino Unido ${ }^{54}$. A primeira Constituição escrita do Canadá, Constitutional Act, de $1867^{55}$, era um estatuto colonial e a promulgação pelo Parlamento do Reino Unido reservou sua autoridade exclusiva para formalmente emendá-la. O Constitutional Act, de 1867, não continha uma regra de emenda abrangente. Ela trouxe, todavia, expressamente a previsão de que as províncias tivessem a autoridade formal para emendar suas respectivas constituições ${ }^{56}$, embora não existisse garantia equivalente de autoridade formal para o Parlamento do Canadá formalmente emendar a Constituição federal. Portanto, existiam apenas duas regras de emenda, uma explícita e outra implícita: uma província poderia emendar sua própria constituição e apenas o Parlamento do Reino Unido poderia emendar a Constituição de Canadá sobre questões afetando exclusivamente o governo federal ou aquelas que repercutiam sobre interesses provincianos e federais.

O Reino Unido posteriormente emendou a Constituição do Canadá para introduzir simetria entre os poderes de emenda federais e provincianos. A emenda garantiu que o Parlamento do Canadá tivesse os mesmos poderes de emenda nas questões puramente federais na Constituição federal que as províncias tivessem quanto as questões puramente provincianas nas suas constituições, como o Constitutinal Act, de 1867, garantiu $^{57}$. Essa simetria foi salutar como questão de forma mas a emenda deixou aberta uma questão no texto constitucional: não havia regra formal clara na Constituição codificada em como formalmente emendar uma questão que envolvesse preocupações federais e provincianas.

Um costume desenvolvido ao longo do tempo em refinar a autoridade da regra formal para emendar questões federais e provincianas do Canadá pertenceu exclusivamente ao Reino Unido. À luz do costume, o Parlamento do Reino Unido poderia

\footnotetext{
${ }^{53}$ Ver Procedimento de emenda constitucional do Canadá, Parte V do Constitution Act, 1982, sendo recolocada como Schedule B no Canada Act 1982, 1982, c 11 (UK) (daqui em diante 'Constitution Act, 1982').

54 Peter W. Hogg, 'A Comment on the Canadian Constitutional Crisis'. Yale Stud World Pub Ord, v. 6, 1980. p. $285,287-88$.

55 The Constitution Act, 1867, 30 \& 31 Victoria, c 3 (UK) (daqui em diante 'Constitution Act, 1867').

56 Constitution Act, 1867, parte VI, seção 92.

${ }^{57}$ América do Norte Britânica (N. 2) Act, capítulo 81, 12, 13 \& 14 Geo 6 (1949). 
formalmente emendar a Constituição do Canadá a partir da requisição do Governo do Canadá onde o Parlamento do Canadá e um número substancial de províncias dessem seu consentimento para a emenda proposta. O costume surgiu antes da prática política: toda vez que o governo do Canadá requeria uma emenda formal afetando a relações entre província e governo federal, o governo tinha que primeiro consultar as províncias afetadas e, claro, tinha que ter assegurado seu consentimento unânime ${ }^{58}$. No julgamento paradigmático de 1981 sobre a transferência da autoridade constitucional da Constituição do Canadá, a Suprema Corte canadense expressamente reconheceu a existência desse costume requerendo o consentimento substancial das províncias para emenda formal afetando os interesses provincianos e federais ${ }^{59}$.

O costume do consentimento substancial da província complementou a regra existente em como formalmente emendar questões de interesse federal-provinciano. Em suas interações dialógicas ao longo de décadas, atores políticos criaram uma prática que em última análise se amadureceu em um costume. Esse costume refinou uma regra existente que até então não admitia ambiguidade: o Parlamento do Reino Unido possuía autoridade para formalmente emendar a Constituição do Canadá em relações federaisprovincianas. Assim como a Corte reconheceu, o costume passou a ser entrincheirado na cultura política canadense sem ter sido entrincheirada no texto constitucional. A nova regra constitucional refinou o processo de emenda em questões federais-provincianas.

É válido indagar se, nos Estados Unidos, a protelação ${ }^{60}$ é um exemplo de costume enraizado onde o conteúdo já é endereçado no texto constitucional. A protelação exige que uma dada medida, moção ou outra votação legislativa no Senado seja apoiada por uma supermaioria de três quintos, ou 60 senadores, a fim de sobreviver. Esse dispositivo legislativo é autorizado pelas regras procedimentais do Senado e requer em sua maior parte que o debate no Senado "seja trazido a um fim" por um voto afirmativo de "três quintos dos senadores devidamente escolhidos e confiados - exceto se uma medida ou moção para emendar as regras do Senado, nesse caso será necessário um voto afirmativo de dois terços dos senadores presentes e votantes", em caso de falha "a matéria pendente no Senado, ou negócios não concluídos, devem ser encerrados antes do

58 Guy Favreau, The Amendment of the Constitution of Canada. Ottawa: Queen's Printer, 1965. p. $12-16$.

${ }^{59}$ Reference re: Resolution to Amend the Constitution, [1981] 1 SCR 753, 904.

60 NT: Filibuster - seria uma espécie de debate que duraria horas e horas acerca de uma proposição legislativa, com os propósitos de protelação, adiamento, obstrução.

Revista Publicum

Rio de Janeiro, v.2, n. 2, 2016, p. 9-44

http://www.e-publicacoes.uerj.br/index.php/publicum

DOI: 10.12957/publicum.2016.27017 
encerramento de qualquer outro" ${ }^{61}$. Senadores passaram a usar a protelação com maior frequência desde a adoção da regra do encerramento (cloture rule) em $1917^{62}$.

Ainda sobre a protelação, uma característica significativa do processo legislativo, aparece em lugar algum do texto da Constituição dos Estados Unidos. A Constituição evidentemente traz com alguma especificidade o processo pelo qual a Câmara dos Deputados $^{63}$ e o Senado devem conduzir sua função de produtor de normas. Por exemplo, a Constituição requer que "toda proposição legislativa que passou pela Câmara dos Deputados e pelo Senado, deve, antes de se transformar em direito, ser apresentada ao Presidentes dos Estados Unidos" ${ }^{\prime 64}$. A Constituição procede com detalhes em como o Presidente deve vetar a proposição, como o Congresso pode derrubar o veto, bem como outras especificações da produção de normas ${ }^{65}$.

A Constituição textual dos Estados Unidos, daí, explica intricadas particularidades do processo legislativo, ainda que não se refira explicitamente à protelação. Acadêmicos são divididos se a protelação é constitucional: alguns argumentam que isso viola as premissas majoritárias constitucionais ${ }^{66}$, enquanto outros argumentam que isso é consistente com os requisitos da Constituição ${ }^{67}$. (Minha própria visão na questão da constitucionalidade é que a protelação é coerente com o poder do Senado de criar suas próprias regras internas, como a Constituição plenamente autoriza ${ }^{68}$.) Posta a constitucionalidade de lado, não é disputado o fato de que a protelação é, como questão descritiva, informalmente entrincheirada dentro de um quadro operativo do processo legislativo senatorial. Nós devemos assim entender a protelação como acréscimo de algo novo no processo de produção de normas textualmente prescrito. Mas esse novo item não é uma emenda formal, pelo menos não adveio como recurso do Artigo $V$ que prescreve os procedimentos constitucionais de mudança ${ }^{69}$; nem é apenas mera prática, já que os atores políticos veem a regra como vinculante.

\footnotetext{
61 Ver Standing Rules of the Senate, Regra XII.

62 Sarah A. Binder et al, 'Tracking the Filibuster, 1917 to 1996'. Am Pol Res,v. 30, 2002. p. 406-407.

63 NT: House of Representatives.

${ }^{64}$ Constituição dos Estados Unidos, art. I, s 7, cl 2.

65 Ibid.

66 Ver, eg, Aaron-Andrew P. Bruhl, 'The Senate: Out of Order?'. Conn L Ver, v. 43, 2011. p. 10411043; Josh Chafetz, 'The Unconstitutionality of the Filibuster'. Conn L Ver, v. 43, 2011. p. 1003-1006; Gerard N. Magliocca, 'Reforming the Filibuster'. Nw U L Ver, v. 105, 2011. p. 303, 303-04.

67 Ver, eg, Catherine Fisk \& Erwin Chemerinsky, 'The Filibuster'. Stan L Ver, v. 49, 1997. p. 181, 245; Michael J. Gerhardt, 'The Constitutionality of the Filibuster'. Const Comment, v. 21, 2004. p. 445482.

${ }^{68}$ Constituição dos Estados Unidos, art. I, s 5, cl 2.

${ }^{69}$ Constituição dos Estados Unidos, art. V:

O Congresso, sempre que dois terços das duas Casas julgarem necessário, deverá propor emendas à Constituição ou, a partir da Aplicação das Legislaturas de dois terços de vários estados, deverá criar
} 
A protelação é costume constitucional que cresceu ao longo do tempo ao refinar o texto existente da Constituição dos Estados Unidos? Eu penso que a resposta é não. A protelação é escrita mas não codificada no texto constitucional, e talvez seja uma norma infraconstitucional que passou a ter um status de quase constitucional. Mas nós não devemos tratar todas as formas de direito não formal como costume. Onde existe uma regra que não aparece no texto constitucional, e atores políticos veem que essa regra é vinculante, isso talvez faça que a regra seja um costume constitucional, ou talvez seja, assim como o caso da protelação, que a regra é vinculante pelo fato de sua qualidade vinculante derivar de um recurso autorizativo. Aqui, a protelação foi autorizada pelo texto da Constituição em si, e a extensão dos atores políticos se sentirem vinculados por essa regra é menos pela sua qualidade normativa e mais pela bona fides constitucional de uma regra passada por um procedimento legislativo.

O vasto corpo de práticas parlamentares estabelecidas, incluindo as regras de procedimento parlamentar, não necessariamente possuem o status de costume. Com o objetivo de distinguir a prática política do costume constitucional, nós devemos retornar ao teste de Jennings, em que aconselha não apenas que o costume existe onde existe precedente e onde os atores políticos se sentem vinculados ao precedente, mas também onde há razão para a regra estabelecida pelo precedente. Tanto a normatividade subjacente à regra, quanto a autopercepção dos atores políticos em aderir à regra ajudam a distinguir o vasto corpo de práticas legislativas de uma esfera mais estreita de costume legislativo. A protelação, apesar de sua permanência ao longo de décadas, importância no processo legislativo e sua policentria, é apenas uma regra meramente escrita do procedimento senatorial que talvez tenha mudado - e, claro, mudou bastante muito recentemente ${ }^{70}$ - por atores políticos. Um costume constitucional resistiria ao tipo de mudança fácil que a protelação recentemente passou.

uma Convenção para propor emendas, em qualquer caso, deverá ser válido a todas intenções e propósitos, como parte da Constituição, quando ratificada por Legislaturas de três quartos de vários estados, ou por Convenções em três quartos assim, de uma forma ou de outra, o Modo de Ratificação deve ser proposta ao Congresso: providenciando que nenhuma emenda criada antes de 1808 deve, sob qualquer hipótese, afetar a primeira e a quarta cláusula da nona seção do primeiro artigo; e nenhum estado, sem seu consentimento, deverá ser privado do direito ao igual sufrágio no Senado.

70 Em novembro de 2013, o Senado modificou a regra da protelação para aplicar a todos, salvo as indicações dos ministros da Suprema Corte. Ver Richard S. Beth \& Anthony J. Madonna, 'The Senate's “Nuclear" Precedent: Implications for Efforts to Control the Filibuster' (22 Agot 2014), at 2 <http://ssrn.com/abstract=2455027> acessad 1 Jun 2015. É válido, por conseguinte, monitorar como a protelação vai acontecer. Por ora, embora seus procedimentos persistam os mesmos, apesar de circunstâncias mais estreitas que serão desenvolvidas.

Revista Publicum

Rio de Janeiro, v.2, n. 2, 2016, p. 9-44

http://www.e-publicacoes.uerj.br/index.php/publicum

DOI: 10.12957/publicum.2016.27017 


\section{Mudança Constitucional Informal por Negação}

Após testar a hipótese de que uma constituição escrita pode se informalmente modificada de duas formas por incorporação - preenchimento de vazio e refinamento - eu agora passo a discorrer sobre como uma constituição pode ser informalmente modificada por duas formas de negação. Mudança informal por negação ocorre onde uma provisão textual entrincheirada é enfraquecida ou modificada pela nova prática política que amadureceu em um costume constitucional. O efeito desse costume se aproxima de uma emenda formal enquanto os atores políticos percebem-na como vinculante e conformadora de suas condutas. Abaixo, eu exponho duas formas de mudança informal por negação: criação de um vazio e substituição.

\section{A. Negação por criação de um vazio}

Um costume constitucional pode funcionalmente, embora não formalmente, remover algo de uma constituição escrita e deixar um vazio em seu lugar. Onde uma provisão textualmente escrita perde sua qualidade vinculante como resultado de não uso e sustentada pelo negação público por atores políticos, essa provisão deve ser entendida como tendo sido informalmente removida do texto. Em outro texto, eu desenvolvi a ideia de "desuso constitucional" a respeito dos poderes de desautorização e reserva na constituição canadense ${ }^{71}$. Desuso constitucional, a qual ocorre em apenas constituições escritas, diferencia do fenômeno de atrofia constitucional, que Adrian Vermeule desenvolveu em conexão com as constituições escritas e não escritas para explicar como poderes constitucionais "passaram do domínio de poderes que são de fato exercitados, para aqueles que podem ser exercitados ou não e para aqueles que talvez não sejam exercitados de modo algum"72. Os dois exemplos de Vermeule são a prerrogativa real no Reino Unido e o poder de empacotar a Suprema Corte nos Estados Unidos, nenhum dos quais está entrincheirado em uma constituição codificada ${ }^{73}$.

Mudança constitucional informal por criação de vazio ocorre onde, assim como o desuso constitucional, um "rearranjo constitucional ocorre informalmente como o resultado da defesa do não uso de uma provisão constitucional entrincheirada" e essa provisão é "expressamente repudiada por atores políticos" depois de que "uma nova

71 Ver Richard Albert, 'Constitutional Amendment by Constitutional Desuetude'. Am J Comp L, v. 62, 2014. p. 641, 656-69.

72 Ver Adrian Vermeule, 'The Atrophy of Constitutional Powers'. Oxford J Leg Stud, v. 32, 2012. p. 421-426.

73 Ibid, p. 424-25. 
regra constitucional substitui a regra repudiada e depois disso estabelece um padrão de conduta futura para os atores políticos"74. Esse novo padrão "exercita um efeito vinculante que se aproxima de uma regra constitucional formal" porque "atores políticos conscientemente seguem o novo padrão, acreditando que estão vinculados a ele"75. Subsequente, essa nova regra constitucional "permeia o principal entendimento costumeiro da constituição" embora, importantemente, “a regra repudiada permanece textualmente entrincheirada"76.

Aqui, eu percebo que a negação criada por um vazio requer que o "novo padrão" seja uma completa negação de uma provisão entrincheirada. O que consequentemente resulta da negação pela criação do vazio é a eliminação não escrita de uma provisão textual. Negação por criação de um vazio nem sempre precisa se preocupar com o exercício do poder ou deveres, mas onde um poder textualmente delegado é repudiado nesse sentido, isto é efetivamente removido do arsenal de um ator constitucional. 0 poder de negação permanece entrincheirado no texto mas é inutilizável. Um novo dever ou poder pode subsequentemente emergir por costume ou implementação formal para preencher o vazio criado pela negação. Como uma questão de definição a partir dessa forma de mudança inconstitucional por costume constitucional, nenhum novo poder ou dever deve ser conferido, caso contrário a emergência de um novo padrão para informalmente modificar uma regra entrincheirada poderia ser melhor classificado como um exemplo de incorporação por refinamento ou, como eu explicarei abaixo, como um exemplo de negação por substituição ${ }^{77}$.

Considere um exemplo de negação por criação de um vazio. No Canadá, o Constitutional Act, de 1867, garante ao governo federal o poder de "reserva" ou "desautorizar" legislação provinciana ${ }^{78}$. Com base no poder de reserva, o governador lugar-tenente de uma província pode restringir uma lei que foi devidamente promulgada por uma legislatura provinciana para instruções futuras do governo federal ${ }^{79}$. Nos lugares em que governador lugar-tenente expressamente não concordou com a lei, essa reserva expira depois de um $a^{80}{ }^{80}$. Com base no poder de desautorização, o governo federal pode repelir uma lei provinciana dentro de um ano de sua adoção por uma legislatura

\footnotetext{
${ }^{74}$ Albert, supra note 66, p. 674-75.

$75 \mathrm{lbid}$, p. 675.

${ }^{76} \mathrm{lbid}$.

77 Comparar supra Seção II.B. com infra Seção III.B.

78 Constitution Act, 1867, parte IV, seção 90.

$79 \mathrm{lbid}$.

80 Ibid.
}

Revista Publicum

Rio de Janeiro, v.2, n. 2, 2016, p. 9-44

http://www.e-publicacoes.uerj.br/index.php/publicum

DOI: 10.12957/publicum.2016.27017 
provinciana ${ }^{81}$. Nenhum desses poderes foram utilizados nos últimos cinquenta anos, ambos foram expressamente repudiados por atores políticos bem como analistas acadêmicos, ainda que os dois poderes estejam entrincheirados até hoje no texto constitucional, escondendo sua ilegitimidade contemporânea e sua toxicidade política ${ }^{82}$. É improvável que qualquer ator político invoque qualquer desses poderes porque, como Andrew Heard explica, "costumes claros e amplamente aceitos surgiram para nulificar os poderes de reservar e desautorização" ${ }^{83}$. Existe agora um vazio funcional porém não formal no texto: esses poderes não são delegações de autoridade politicamente destacáveis e nenhum poder federal textualmente entrincheirado emergiu no seu lugar para preencher o vazio.

Nós podemos entender esse fenômeno em termos de um costume constitucional. Um costume que surgiu para proibir atores políticos de usar os poderes de reserva e desautorização. A natureza desse costume é anulatória e inibidora: primeiro, ela anula parte do texto constitucional, interpretando as palavras de ambos os poderes como ineficaz e inexigível, embora as palavras continuem a refletir a intenção expressa dos autores constitucionais; e segundo, o costume inibe o antes operativo texto, servindo como barreira para estender os dois poderes.

Mas esse fenômeno é distinto da negação por substituição, que eu vou discutir abaixo. Negação por criação de um vazio obriga um ator político a evitar agir tal como o texto constitucional autoriza, mas negação por substituição autoriza o ator político agir de uma forma que o texto constitucional proíbe. Negação por criação de um vazio cria um vazio no texto onde nada existia: atores políticos antes validamente possuíam o poder de escolher agir de uma forma que o texto autorizava, mas agora, como resultado do costume proibindo o uso do poder, atores políticos não devem mais escolher o curso. Em contraste, negação por substituição agora autoriza atores políticos escolherem algo que diretamente entrará em contradição com o texto constitucional. Em ambos os casos, a chave é discricionariedade. No caso de negação por criação de vazio, atores políticos não mais se valem da discricionariedade de invocar uma provisão entrincheirada, mas no caso de negação por substituição, atores políticos desfrutam da discricionariedade de se opor ao que o texto constitucional requer. Eu discuto negação por substituição na seção seguinte.

\footnotetext{
$81 \mathrm{lbid}$.

${ }^{82}$ Albert, supra note, p. 66, 664-65.

${ }^{83}$ Heard, supra note, p. 23, 159.
}

Revista Publicum 


\section{B. Negação por substituição}

Um costume constitucional pode também contradizer com uma Constituição escrita. Em contraste à negação por criação de vazio - em que provisão constitucional entrincheirada perde sua qualidade vinculante e efetivamente deixa de estar presente no texto, ainda que textualmente presente - negação por substituição vai além negando um texto constitucional entrincheirado: ela cria um dever, um poder, uma obrigação ou outra regra, todas conflitantes. Negação por substituição ocorre onde um costume emerge como resultado de uma prática política que conflita com uma regra entrincheirada no texto constitucional. Essa mudança constitucional informal efetivamente substitui uma provisão constitucional escrita com uma prática política não-escrita que desafia o significado claro do texto constitucional.

Desafiar um texto constitucional poderia implicar em si mesmo diversos significados. Isso pode significar que uma prática política envolvida é inconsistente com o significado intencional do texto constitucional, ou o significado costumeiro, ou até mesmo seu significado original. A não ser que especifiquemos qual desses significados rege ou deve reger nosso entendimento sobre o texto constitucional, nós estamos suscetíveis em discordar sobre se uma dada prática política possa ser inconsistente com o texto à luz de uma particular interpretação do texto. Claro, como o ministro da Suprema Corte dos Estados Unidos John Marshall sugeriu num antigo caso de interpretação constitucional, uma grande batalha sobre regimes com constituições textuais é como interpretar o texto e qual a metodologia interpretativa intérpretes deveriam usar. Uma constituição, ele sugeriu, deve necessariamente ser interpretada com o objetivo de algum uso funcional ${ }^{84}$.

Ainda tratando uma interpretação judicial constitucional autorizada como um desafio dos riscos de o texto entrar ruir cada uma das quatro formas de mudança informal por costume em uma única abrangente categoria. Qualquer decisão judicial autorizada por uma última Corte nacional de recursos poderia ser interpretada como uma mudança informal por costume. Por exemplo, uma decisão da Suprema Corte dos Estados Unidos em que a Primeira Emenda previne o Congresso de impor restrições nas despesas eleitorais por corporações poderia ser classificada como um exemplo de incorporação por refinamento ${ }^{85}$. Ou o primeiro julgamento da Suprema Corte do Canadá em interpretar a Charter of Rights and Freedoms, em que envolviam cidadania e direitos de mobilidade, poderia ser ela mesma classificada como um exemplo de incorporação por preenchimento de um vazio, enquanto passou a ser a primeira definição autorizada de um direito

${ }^{84}$ McCulloch v Maryland, (1819) 17 US (4 Wheat) 316, 407.

85 Ver Citizens United v Federal Elections Comm'n, (2010) 130 S Ct 876.

Revista Publicum

Rio de Janeiro, v.2, n. 2, 2016, p. 9-44

http://www.e-publicacoes.uerj.br/index.php/publicum

DOI: 10.12957/publicum.2016.27017 
entrincheirado que até então havia sido juridicamente vazio ${ }^{86}$. É útil para nossos propósitos, então, distinguir interpretação judicial de prática política vinculante autorizada por interpretação judicial ${ }^{87}$. Interpretação judicial sozinha não cria um costume. Ela requer que atores políticos regularizem uma prática que é apoiada por uma boa razão e que ao longo do tempo passe a ser vista como obrigatória. Aceitação talvez ocorra seja por aprovação ativa, seja por aquiescência passiva. Em qualquer caso, onde atores políticos se engajam em uma prática perseguindo uma interpretação judicial autorizada - uma prática que é tensão com o claro significado do texto constitucional isso pode gerar um costume que informalmente mude a Constituição escrita por Negação.

Por exemplo, nos Estados Unidos, a Contract Clause e a Treaty Clause foram contraditadas por práticas políticas que agora autorizam o oposto do que o texto constitucional em seu significado claro. A Contract Clause, cujo texto não admitia exceções ao estritamente proibir estados de "enfraquecer a obrigação dos contratos" 88 , agora permite a intrusão do estado nos contratos ${ }^{89}$. Desde a Era da Depressão, quando a Suprema Corte aprovou pela primeira vez essa prática como uma medida de estreita emergência, estados continuaram a agir em direto conflito com o texto ${ }^{90}$. Como exemplo adicional: o poder de negociar tratado confere ao presidente o "poder, pelo e com o conselho e consentimento do Senado, de estabelecer tratados, aprovados por dois terços dos Senadores presentes..."91. Ainda na Era Moderna, passou a ser prática comum para o presidente evitar a confirmação do Senado ao entrar acordos apenas pelo Executivo que alcançam os mesmos fins funcionais dos tratados ${ }^{92}$. A Suprema Corte efetivamente aprovou essa prática, recusando a regra de que os "acordos executivos" contornam o requisito constitucional do consentimento pelo Senado ${ }^{93}$. Esses são os exemplos de mudança informal como resultado de negação por substituição onde uma prática política não escrita se amadurece a um costume constitucional que é inconsistente com o texto.

\footnotetext{
${ }^{86}$ Ver Law Society of Upper Canada v Skapinker, [1984] 1 SCR 357.

87 Ver Mark Tushnet, 'Constitutional Workarounds'. Tex L Ver, v. 87, 2009. p. 1499-1510.

88 US Const, art I, s 10, cl 1 (1789).

89 Ver Home Building \& Loan Association v Blaisdell, 290 US 398 (1934) (autorizando a lei de Minnesota restringir os hipotecários de intervirem na propriedade).

90 Jed Rubenfeld, Revolution by Judiciary: The Structure of American Constitutional Law. Harvard University, Press 2005. p. 67-68.

91 US Const., art. II, seção 2.

92 See Joseph P. Tomain, 'Executive Agreements and the Bypassing of Congress'. J Int'I L \& Econ, v. 8, 1973. p. 129, 129-32.

93 Ver Am Ins Ass'n v Garamendi, 539 US 396, 415 (2003); Dames \& Moore v Reagan, 453 US 654, 682-87 (1981); US v Pink, 315 US 203, 229-30 (1942); US v Belmont, 301 US 324, 330-31 (1937).
} 


\section{Mudança Constitucional Informal e o Estado de Direito}

O fenômeno da mudança informal por costume constitucional gera questões importantes sobre a natureza das constituições escritas, o significado da mudança constitucional, e se e como distinguir entre as formas de mudança informal por costume. Igualmente importante, é a inter-relação entre constituições escritas e costumes constitucionais, especificamente se uma disjunção entre texto constitucional e normas constitucionais não escritas enfraquece os valores democráticos do estado de direito - a saber, previsibilidade, prestação de contas e transparência - valores que seguem da textualidade. Na Parte I, eu ofereci pensamentos preliminares sobre essas questões e sugeri por que é importante para o constitucionalismo a tentativa de respondê-las.

Falar de constituição, sem mais, gera duas importantes questões: o que conta como "Constituição" e como nós interpretamo-la quando identificamos? ${ }^{94}$ É claramente incorreto responder que a constituição em um regime textual é simplesmente o que aparece no texto constitucional. A Constituição dos Estados Unidos, por exemplo, inclui um componente não escrito consistindo em costumes e práticas, bem como seus princípios e valores subjacentes ${ }^{95}$. A Suprema Corte frequentemente reconheceu, notadamente sobre política externa, que a alocação de poderes da constituição pode ser modificada onde, ao longo do tempo, uma instituição de governo se engaja na prática com aprovação, sem objeção, ou em face da aquiescência de outra instituição de governo que poderia, de maneira concebível, gerar um pedido legítimo de que a prática conflita com sua própria autoridade delegada ${ }^{96}$. Esses desenvolvimentos constitucionais não escritos são, como John Gardner explica, nem expressa, nem intencionalmente feito, mas, ao contrário, surgem da confluência de ações de múltiplos atores ao longo do tempo ${ }^{97}$. Elas são constitucionais ainda que não apareçam no texto.

\section{A. A congruência entre texto constitucional e prática política}

O texto codificado é importante por razões tanto formais e funcionais, mas o que mais importa é como o texto é entendido por seus sujeitos. Tom Ginsburg desenvolve esse ponto com um exemplo útil: "uma regra constitucional dizendo que as eleições devem acontecer em um final de semana, ao longo do tempo, pode representar um entendimento intersubjetivo de que a votação sempre deva acontecer aos domingos, ou

\footnotetext{
94 Sanford Levinson, “'The Constitution" in American Civil Religion'. Sup Ct Ver, 1979. p. 123, 136.

95 Thomas C. Grey, 'The Uses of an Unwritten Constitution'. Chi-Kent L Ver, v. 64, 1988. p. 211.

${ }^{96}$ David J. Bederman, Custom as a Source of Law. Cambridge University Press, 2010. p. 110-12.

97 John Gardner, Law as a Leap of Faith. Oxford University Press, 2012. p. 65-74.
} 
mesmo às terças-feiras" 98 . Ele continua, "contanto que os sujeitos pensem que o texto marque seu significado constitucional, não é necessário carregar qualquer relação com a realidade"99. O ponto não é que "o texto seja desimportante", mas o fato de que "ao longo do tempo, o texto da Constituição é mais provável que importe menos e menos como uma questão formal” ${ }^{100}$. Aqui, a ilustração comparativa de Raz é instrutiva:

(Uma Constituição que se adaptou por "interpretações inovadoras") é ainda a Constituição adotada há 200 anos, assim como uma pessoa que vive em uma casa no Século XVIII vive em uma casa construída há 200 anos. Essa casa foi consertada, acrescida, e modificada várias vezes desde então. Mas ainda é a mesma casa e a mesma Constituição.

Uma pessoa talvez, é claro, recuse em redecorar a casa ou modificar suas janelas, dizendo que ela não seria a mesma. Em certo sentido é verdade que uma Constituição antiga não é igual que uma Constituição nova, assim como uma pessoa idosa não é igual a mesma pessoa jovem. Igualdade ${ }^{101}$ nesse sentido não significa igualdade de identidade (a pessoa idosa é idêntica com a pessoa jovem que outrora fora). É igualdade no tocante a todas propriedades intrínsecas do objeto. ${ }^{102}$

Atores políticos frequentemente fazem mudanças na mobília da arquitetura constitucional, ao estabelecer novas interpretações autorizadas do texto ou, formalmente, ao acrescer ou remover parte do texto por meio de emenda constitucional, mas essas são mudanças à constituição e não $d a$ constituição em si. A questão é se uma mudança envolve uma mera mobília ou algo mais básico que essa mudança na constituição significaria fundamentalmente refazer todo o trabalho como uma questão de interpretação e desenho. Alguns estados constitucionais expressamente distinguem entre mudanças de pequena escala e de larga escala, esse referido como emenda e aquele como revisão, enquanto outros estados deixam a questão sem previsão no texto constitucional, e daí ser resolvida por processos judiciais e políticos ${ }^{103}$. Outros deixam claro ou sugerem os valores constitucionais que constituem a identidade da constituição

98 Tom Ginsburg, 'Constitutional Specificity, Unwritten Understandings and Constitutional Agreement' in A. Sajó \& R. Uitz (eds.), Constitutional Topography: Values and Constitutions. Eleven International Publishing, 2010. p. 69, 77.

99 lbid.

100 Ibid.

101 NT: No original "Sameness"

102 Joseph Raz, Between Authority and Interpretation: On the Theory of Law and Practical Reason. Oxford University Press, 2009. p. 370.

103 Ver Richard Albert, 'The Structure of Constitutional Amendment Rules'. Wake Forest L Ver, v. 49, 2014. p. $913,929-35$. 
ao designá-los como cláusulas pétreas ${ }^{104}$, e consequentemente visam remover completamente dos caprichos do processo judicial e político.

Por mais que eles tentem, o Poder Constituinte não pode congelar seu significado preferido do direito constitucional ao longo do tempo ${ }^{105}$, nem por meio de vedações a emendas, sejam formais ${ }^{106}$, sejam interpretativas ${ }^{107}$, nem mesmo por especificidade constitucional $^{108}$. Claro, o esforço de congelar ao longo do tempo revela uma patologia que é de vez em quando evidente no desenho constitucional: a confiança de que os autores possuem se si mesmos e a desconfiança que nutrem sobre gerações futuras ${ }^{109}$. 0 esforço de congelar o tempo gera o problema da "mão morta" no direito constitucional, que por sua vez cria um déficit democrático para as gerações que sucedem ${ }^{110}$. Esse déficit democrático é mais problemático no caso das cláusulas pétreas ${ }^{111}$, mas qualquer texto constitucional intencionalmente rígido corre o risco de perder sua legitimidade fundada no consentimento popular ${ }^{112}$. A mesma aspiração em congelar o tempo é evidente na interpretação constitucional originalista, embora eu resista descrevê-la como patologia, porque originalismo é um dos vários caminhos razoáveis para dar significado ao texto cujo significado possa admitir uma multiplicidade de significados morais, legais e sociologicamente legítimos ${ }^{113}$.

Para os propósitos presentes, meu ponto de partida é o significado do texto no período em que é lido por um leitor razoável que é sujeito ao seus constrangimentos e compulsões. Leitores razoáveis do texto constitucional não deveriam perceber a dissonância entre o que o texto diz e como atores políticos conduzem eles mesmos, ou como o intérprete autorizado do texto entende que o texto obriga os governados e os governantes, ou como os leitores eles mesmos podem perceber seus direitos e deveres.

${ }^{104}$ Ver Richard Albert, 'Amending Constitutional Amendment Rules' (em fila para edição 2015) Int'l J Const $L$.

105 Sanford Levinson, 'Law as Literature'. Tex L Ver, v. 60, 1982. p. 373, 376-77.

106 Cláusulas pétreas são indefensáveis diante de movimentos revolucionários. Ver John R. Vile, 'Limitations on the Constitutional Amending Process'. Const Comment, v. 2, 1985. p. 373-375.

107 Porém, atores políticos talvez inovem novos métodos para alterar a Constituição mesmo onde o texto é interpretativamente intransponível. Ver Richard Albert, 'Constructive Unamendability in Canada and the United States'. Sup Ct L Ver, v. 67, 2014. p. 181, 210-15.

108 Ginsburg, supra, p. 93.

109 Ver Sanford Levinson, 'The Political Implications of Amending Clauses'. Const Comment, v. 13, 2016. p. 107, 112-13.

${ }^{110}$ Ver Andrew Friedman, 'Dead Han Constitutionalism: Honduras and the Danger of Eternity Clauses in New Democracies' Mexican L Ver, v. 4, 2011. p. 77.

${ }^{111}$ Ver Richard Albert, 'Constitutional Handcuffs'. Ariz St LJ, v. 42, 2010. p. 663-667.

112 Walter Dellinger, 'The Legitimacy of Constitutional Change: Rethinking the Amendment Process'. Harv L Ver, v. 97, 1983. p. 386, 386-87.

113 Para uma contundente defesa atual e explicação do originalismo, ver Lawrence B. Solum, 'The Fixation Thesis: The Role of Historical Fact in Original Meaning' (February 3, 2015), at 18-29 http://ssrn.com/abstract=2559701 acessado 1 Jun 2015.

Revista Publicum

Rio de Janeiro, v.2, n. 2, 2016, p. 9-44

http://www.e-publicacoes.uerj.br/index.php/publicum

DOI: 10.12957/publicum.2016.27017 
Nessa visão, o exemplo de Ginsburg de uma regra textual peremptória requerente as eleições no final de semana, mas que por pela prática possa ser interpretada como ocorrência na terça, seria problemática onde leitores razoáveis percebem que o texto constitucional reflete de maneira não acurada a regra de votação atual ${ }^{114}$. Tal dissonância põe em risco debilitar o estado de direito e os valores democráticos que são intencionados em servir. Mas eu suspeito que um leitor razoável é menos propenso a perceber a disjunção entre texto e prática quanto ao poder textualmente delegado do Congresso "cunhar moeda, e regular seu valor"115 e a prática prevalente de imprimir papel-moeda até hoje não deve ser entendida exclusivamente a moedas.

Lendo o texto como um leitor razoável que está sujeito a ele faria, assim, privilegia o significado público presente ${ }^{116}$. A recompensa é o núcleo da promessa do estado de direito: alertar de maneira justa a partir do texto que existe uma simetria entre as expectativas que o texto cria e os resultados que ele gera ${ }^{117}$. Existe uma ameaça ao estado de direito onde o texto que deveria ser vinculante não é mais relevante ou reconhecido pelos que são governados ${ }^{118}$. A ameaça é dupla, as duas quanto à regra do direito e quanto à Constituição codificada em si. Onde, por exemplo, o bill of rights promete um salário-mínimo mas as pessoas se encontram subempregadas ou sem trabalho, o povo irá concluir que a Constituição não significa o que ela diz, e isso talvez cause ao longo do tempo a perda de fé nas instituições públicas ${ }^{119}$. Como Ginsburg sugere, a disjunção entre texto e realidade talvez seja menos problemática ao longo do tempo de uma democracia constitucional madura ${ }^{120}$. Mas ainda permanece excepcionalmente problemática em nações tentando criar uma nova cultura de constitucionalismo ${ }^{121}$.

Embora o texto constitucional não possa por conta própria um garantidor do estado de direito, ele pode ser um agente do estado de direito enquanto uma constituição codificada pode ser tanto promotora da democracia quanto protetora ${ }^{122}$. Levar o texto a sério significa apreciar o que as pessoas leem e se referir a isso com o intuito de "definir

114 Ginsburg, supra, p. 93.

115 Constituição dos Estados Unidos, art. I, seção 8, cl. 5.

116 Vários acadêmicos adotaram essa visão, que Larry Solum descreve como teoria "leitores contemporâneos". Ver Solum, supra, p. 62-65.

117 Ver Caleb Nelson, 'What is Textualism?'. Va L Ver, v. 91, 2005. p. 347-352.

118 'Textualism as Fair Notice'. Harv L Ver, 123, 2009. p. 542-563.

119 Richard Albert, 'Counterconstitutionalism'. Dalhousie LJ, v. 31, 2008. p. 1, 35.

120 Ginsburg, supra, p. 93.

${ }^{121}$ Cass Sunstein, 'Against Positive Rights'. E Eur Const Ver, v. 2, 1993. p. 35-37

122 Constituições codificadas servem para outras funções importantes, incluindo a coordenação do comportamento e criando um arcabouço para elaboração da commom law. Ver Andrew B. Coan, 'The Irrelevance of Writtenness in Constitutional Interpretation'. U Pa L Ver, v. 158, 2010. p. 1025, 1047-71. Constituições codificadas também servem como funções expressivas. Ver Cass R. Sunstein, 'On the Expressive Function of Law'. E Eur Const Ver, v. 5, 1996. p. 66-67.

Revista Publicum

Rio de Janeiro, v.2, n. 2, 2016, p. 9-44

http://www.e-publicacoes.uerj.br/index.php/publicum

DOI: 10.12957/publicum.2016.27017 
um vocabulário básico de liberdade para os cidadãos ordinários"123. Esse tipo de "textualismo popular", para pegar emprestada a expressão de Mark Tushnet, é o "primeiro princípio interpretativo" para não-juristas que buscam entender os direitos e deveres a partir do texto constitucional que os governa ${ }^{124}$. Além da função de construir a democracia para constituições escritas, ele também possui uma função de construir a nação: a textualidade da constituição faz com que isso seja uma força para constituir uma única nação como povo, cujas origens, crenças e aspirações talvez se diferenciem em várias hipóteses ${ }^{125}$. Akhil Amar captura esse ponto essencial sobre constitucionalismo, conectando textualidade à democracia nos Estados Unidos:

Enfatizar a textualidade da Constituição - sua textualidade geral e suas provisões textuais específicas - possui certos valores democráticos. A Constituição é um documento compacto que a maioria dos americanos pode ler. Com um esforço modesto, até mesmo leigos podem se familiarizar com suas palavras e layout básico. [...] O texto do documento em si constitui um ponto democrático focal - e um local de espaço público, uma linguagem comum - que pode estruturar a conversa da população americana geral já que ele pondera as questões mais fundamentais e, de vez em quando, divisivas na república de cidadãos iguais. Certas formas de interpretação constitucional não textual são inerentemente excludentes, requerendo familiaridade íntima com a vasta quantidade de estudo de casos e a arte sutil de análise doutrinária, ou domínio de vasta ou parte da história, ou fluência na obscura filosofia política. ${ }^{126}$

Essas são algumas das forças que dirigiram a textualização da Constituição dos Estados Unidos. O documento, tratado como a escritura da cultura da "reverência à Constituição americana" é tanto um instrumento jurídico quanto um "símbolo sagrado" não tão diferente da bandeira ${ }^{127}$. Na tradição americana moderna de textualidade, textos são reverenciados como instrumentos de ordem social, seja religioso ou político, ou, claro, o que para Thomas Paine era a reunião dessas duas ordens na Constituição, a qual ele via como uma "bíblia política"128. Na fundação americana, o texto carregava força moral

${ }^{123}$ Akhil Reed Amar, 'Textualism and the Bill of Rights'. Geo Wash L Ver, v. 66, 1998. p. 1143-1144.

124 Mark Tushnet, 'Citizen as Lawyer, Lawyer as Citizen'. Wm \& Mary L Ver, v. 50, 2009. p. 13791381.

125 Akhil Reed Amar, 'A Few Thoughts on Constitutionalism, Textualism, and Populism'. Fordham $L$ Ver, v. 65, 1997. p. 1657-1658.

${ }^{126}$ Akhil Reed Amar, 'Intratextualism'. Harv L Ver, v. 112, 1999. p. 747, 796.

127 Thomas C. Grey, 'The Constitution as Scripture'. Stan L Ver, v. 37, 1984. p. 1, 17.

128 Thomas Paine, 'Rights of Man, Part II. Combining Principles and Practice' in The Political Writings of Thomas Paine, Vol. 2. J.P. Mendum, Boston, 1856. p. 145, 180-81.

Revista Publicum

Rio de Janeiro, v.2, n. 2, 2016, p. 9-44

http://www.e-publicacoes.uerj.br/index.php/publicum

DOI: 10.12957/publicum.2016.27017 
como um ato de autodefinição acessível e tangível ${ }^{129}$. Sua formulação, "singularmente breve e expressiva"130, convidava americanos para descobrirem o documento e internalizarem suas regras ${ }^{131}$, tanto para governar suas condutas individuais, quanto para monitorar cuidadosamente os limites que vinculam a ação governamental permissiva ${ }^{132}$.

A função principal de uma constituição codificada, então, escrita pelo Chief Justice John Marshall em Marbury v. Madison, decidida nos anos iniciais da nova república americana, é "estabelecer certos limites não transcender" a partir das instituições de governo $^{133}$. Todas instituições do governo, incluindo cortes, "estão vinculadas pelo instrumento" 134 cujo núcleo "mais fundamental"135 e "essencial"136 é a constituição em si como "superior, Paramount Law, imodificável pelos meios ordinários"137. Onde uma constituição escrita prescreve limites que se forem transgredidos não acarretam sanção, então a transgressão do texto constitucional "reduz à nada o que nós julgávamos ser a maior evolução das instituições políticas"138, notadamente sua textualidade. Isso sugere uma norma básica do governo democrático que funciona como uma melhor prática para regimes com constituições textuais: texto e prática deveriam ser consistentes, ausentes razões extraordinárias.

A possibilidade do julgamento prático contra o texto é o que fez uma Constituição escrita tão importante para Marshall como um instrumento de governo democrático. Lon Fuller também via virtude no que ele chamava de "congruência entre regras como anunciadas e sua administração atual"139. Mas congruência para Fuller não era, como deveria ter sido para Marshall antes dele, algo que apenas uma constituição escrita poderia ajudar garantir mas ao contrário era um elemento essencial do estado de direito, esteja ou não em uma democracia com constituição escrita. Congruência era um dos oito elementos que Fuller identificava como requisitos para o estado de direito, incluindo criar

129 Ver Gordon S. Wood, The Creation of the American Republic 1776-1787. University of North Carolina Press, 1998. P. 260.

130 Joseph Story, 'The Science of Government' in William W. Story (ed), The Miscellaneous Writings of Joseph Story. C.C. Little and Brown, 1852. p. 622.

${ }^{131}$ Akhil Reed Amar, America's Constitution: A Biography. Random House, 2005. p. xi.

132 Ver Richard Albert, 'The Cult of Constitutionalism'. Fla St L Ver, v. 39. 2012. p. 373, 410-12.

133 Marbury v Madison, 5 US (1 Cranch) 137, 176 (1803).

134 Ibid, p. 180.

135 Ibid, p. 178.

136 Ibid, p. 180.

137 Ibid, p. 179.

138 Ibid, p. 178.

139 Lon L. Fuller, The Morality of the Law. Yale University Press, 1964. p. 39. 
regras claras como expectativas claras e publicar essas regras com o objetivo de constranger os governantes e dar satisfação aos governados ${ }^{140}$.

Fuller e Marhsall não estavam sozinhos, claro, em associar o estado de direito com essa aspiração de congruência entre direito e ação. Friedrich Hayek e A. V. Dicey em particular defendiam proposições similares, a saber que "despido de todas tecnicalidades, [o estado de direito] significa que o governo em todas suas ações é vinculada por regras fixadas e anunciadas de antemão - regras que torna possível prever com certeza de como a autoridade usará seus poderes coercivos em dadas circunstâncias e planejar seus interesses os interesses individuais baseados no exercício desse conhecimento" ${ }^{141}$ e que "o estado de direito se contrasta com todo sistema de governo baseado no exercício por pessoas com poderes de coagir de modo amplo, arbitrário e discricionário" ${ }^{142}$. Joseph Raz, de igual modo, sita o estado de direito em termos de expectativas que a produção jurídica será "guiada por regras abertas, estáveis, claras e gerais"143 que permitem os governados sustentarem os governos transparentes. A centralidade da congruência à regra do direito, então, torna incontroverso para admitir que definir o princípio do estado de direito é que o "poder político não será exercido, exceto esteja de acordo com os procedimentos e constrangimentos prescritos por leis que sejam publicamente conhecidas" ${ }^{144}$.

O estado de direito evidentemente não requer textualidade. $\mathrm{O}$ estado de direito existe e claramente próspera em jurisdições sem uma constituição codificada. Mas uma constituição codificada, como Marhsall bem sustentou, pode ajudar a promover os valores democráticos de transparência, prestação de contas e previsibilidade do estado de direito $^{145}$. Textualidade encantou Marshall porque facilitava o dever judicial de avaliar a constitucionalidade da conduta em face do padrão previsto no texto constitucional. Mas se a conduta satisfizesse as restrições do texto é apenas uma parte importante da relação entre texto e prática. $\mathrm{O}$ oposto também é importante: se o texto corretamente reflete 0 que as normas aceitas informam, modelam, compelem ou constrangem práticas políticas.

\section{B. Mudança constitucional informal por costume constitucional}

140 Ibid, p. 39.

${ }^{141}$ F.A. Hayek, The Road to Serfdom. Routledge, 1944. p. 75-76.

${ }^{142}$ A.V. Dicey, Introduction to the Study of the Law of the Constitution. 8a edição. Liberty Fund, 1915. p. 110.

143 Joseph Raz, The Authority of Law: Essays on Law and Morality. Oxford University Press, 2009. p. 214.

${ }^{144}$ Fred D. Miller, Jr., 'The Rule of Law in Ancient Greek Thought' in Mortimer Sellers \& Tadeusz Tomaszewski, (eds), The Rule of Law in Comparative Perspective. Springer, 2010. p. 11, 11.

$145 \mathrm{Em}$ outro trabalho eu expliquei como o estado de direito serve a esses valores democráticos. Ver Richard Albert, 'Constitutional Amendment by Stealth'. McGill LJ, v. 60, 2015. 
Normas constitucionais não escritas podem e efetivamente existem com textualidade de um regime constitucional escrito. Mas a relação se torna problemática para o estado de direito onde uma norma constitucional não escrita não apoia nem completa a constituição escrita mas, ao invés disso, a derroga ${ }^{146}$. As quatro formas de mudança informal por costume constitucional sublinha incongruências entre texto e prática que põe ameaças em diferentes degraus ao estado de direito. Cada uma das quatro formas de mudança constitucional informal por costume constitucional pode ser traçada ao longo de uma escala linear de congruência entre texto e prática, onde a congruência perfeita representa conformidade ótima com o estado de direito e perfeita não congruência reflete sua total violação. Nessa escala, da maior para a menor congruência entre texto constitucional e prática política, as quatro formas podem ser ordenadas como se segue: incorporação por preenchimento de vazio no maior nível de congruência, embora longe da congruência perfeita de um texto e uma prática consistentes; negação por substituição no menor nível de congruência; e incorporação por refinamento e negação por criação de vazio geralmente em algum lugar entre as outras duas, em que pese sua determinação ser mais ou menos congruente com o estado de direito depender da natureza do costume atual.

É válido questionar qual o padrão a ser utilizado para avaliar a conformidade com os valores de transparência, previsibilidade e prestação de contas do estado de direito. A Suprema Corte dos Estados Unidos isolou o ponto crucial da questão no caso New York v. United States, um caso ligado à Lei da Política Pública de Lixo Radioativo ${ }^{147 \_148}$ de 1985 . A lei do Congresso exigia que estados dispusessem sobre o lixo radioativo gerado dentro de suas fronteiras e criou três tipos de estratégias para assegurar sua cooperação: dar aos estados dinheiro se eles cumprissem a lei; recusar acesso a certas instalações se o estado perdesse prazos importantes para a disposição do lixo; e a responsabilização civil do estado decorrente dos danos gerados pelo lixo, se o estado falhasse em providenciar a disposição no prazo adequado ${ }^{149}$. O estado de Nova York desafiou com êxito a terceira dessas pressuposições federalistas da 10a Emenda, alegando que o Congresso inadmissivelmente obrigou Nova York a regular de maneira peculiar essa área ${ }^{150}$, e ao fazer isso "desatou" o processo legislativo" ${ }^{151}$.

Ao julgar o desincentivo da propriedade inconstitucional, a maioria sublinhou as condições que debilitam transparência, previsibilidade e prestação de contas, as mesmas

\footnotetext{
${ }^{146}$ Cf Amar, supra, p. 16, xi.

${ }_{147}$ New York v United States, 505 US 144 (1992).

148 Low-Level Radioactive Waste Policy Amendments Act

149 Ibid, p. 152-54.

$150 \mathrm{lbid}$, p. 160.

151 Ibid, p. 176
}

Revista Publicum

Rio de Janeiro, v.2, n. 2, 2016, p. 9-44

http://www.e-publicacoes.uerj.br/index.php/publicum

DOI: 10.12957/publicum.2016.27017 
condições que talvez nos guiem em avaliar se a disjunção entre texto e prática é problemática para um leitor razoável do texto constitucional. Como a Corte explicou, onde o governo federal obriga o estado a regular, como se pretendia fazer por meio dessa lei, “a prestação de contas pelo governo federal e seus agentes é diminuída"152. A Corte continuou:

[O]nde o governo federal obriga o estado para regular, talvez recai sobre os agentes do estado o peso da desaprovação pública, enquanto os agentes federais que inventaram o programa regulatório talvez persistam insulados das ramificações eleitorais de sua decisão. Prestação de contas é, então, diminuída quando, devido à coerção federal, agentes estatais eleitos não podem regular de acordo com a visão do eleitorado local em questão antecipada por regulação federal. ${ }^{153}$

A Corte aqui estava preocupada sobre como, diante das regras não tão claras sobre responsabilidade, os cidadãos poderiam identificar atores políticos - agentes federais ou de Nova York - cuja ação os afetou e, por sua vez, como cidadãos poderiam efetivamente expressar sua satisfação ou insatisfação onde eles tivessem dificuldade em identificar os atores políticos que começaram com isso. O risco de o governo federal comandar um estado era esse, como a Corte reconheceu, que os cidadãos talvez julgassem o estado como responsável por uma ação que foi feita pelo governo federal. A Corte sublinhou que essa intenção não era de proteger estados especificamente mas ao contrário, respeitar tanto a estrutura do federalismo americano e a capacidade dos cidadãos saberem qual nível de governo fora responsável por uma ação particular. A Corte reconheceu que nenhum nível de governo quereria ser associado com decisões impopulares ou outras, e ao fazê-las deixarem os cidadãos mal informados sobre quais atores políticos efetivamente decidiram e também sem deixá-los com algum instrumento judicial ${ }^{154}$.

No mesmo sentido, os interesses dos cidadãos como sujeitos da constituição não são bem servidos onde há inconsistência entre o que o texto diz e o que significa na prática. Essa inconsistência complica a missão de um leitor razoável do texto responsabilizar aqueles que deveriam estar vinculados a ele. Consequentemente, onde o texto admite essa disjunção, ele se revela como não transparente e de pouca utilidade para prever a conduta oficial futura. Desenhando a partir desse entendimento dos valores

\footnotetext{
152 Ibid, p. 168.

$153 \mathrm{lbid}$, p. 168-69.

154 Ibid, p. $182-83$.
}

Revista Publicum 
democráticos do estado de direito, nós podemos avaliar quão bem cada uma das quatro formas de mudança informal por costume conforma nossa expectativa prevista no texto.

Primeiro, considere a incorporação por preenchimento de vazio. Aqui, o significado de constituição codificada muda como um resultado do entrincheiramento de um costume constitucional que preenche um espaço no texto. Eu sugeri como um exemplo o costume dos dois mandatos presidenciais, que foi uma norma constitucional não escrita obrigando o presidente não se candidatar ao terceiro mandato, salvo uma emergência nacional sugerisse a necessidade de continuidade na presidência. O costume dos dois mandatos foi finalmente proposta e ratificada como emenda formal em 1951, mas havia se tornado vinculante muito antes do entrincheiramento textual. Tal como sugerido, a razão é um costume desenvolvido depois de George Washington estabelecer o precedente que seus sucessores seguiram.

Onde, tal como o costume dos dois mandatos presidenciais, o texto não estabelece requisito ou padrão relevante, existe pequeno terreno para arguir que o estado de direito é comprometido pela emergência de um costume constitucional exigindo ou impedindo certa conduta. Não havia rompimento com as expectativas públicas estabelecidas no texto, que passaram a ser escritas, fossem expressa, implícita ou negligentemente para acomodar qualquer prática política de elegibilidade e reeleição que se aconteciam entre os atores políticos. Tivesse o costume washingtoniano sido diferente - por exemplo, exigindo que os presidentes com dois mandatos concorressem a um terceiro - o vazio no texto poderia tão bem ter acomodado essa forma alternativa de mudança constitucional informal. Isso não teria dado ensejo a uma disjunção entre texto e prática, e consequentemente não teria debilitado os valores de previsibilidade, transparência e prestação de contas do estado de direito. Essa é a natureza da mudança constitucional informal como resultado da incorporação por preenchimento de vazio: não existe contradição textual nem mesmo mudança ao texto por causa do silêncio em questão.

De outro modo, mudança informal como resultado de negação por substituição é uma completa violação dos valores de transparência, prestação de contas e transparência do estado de direito. Substituição cria um conflito direto entre texto e prática. Os governados, nesse caso, não possuem padrões de referência em que os governos vão se ancorar, nem padrões que ancorarão esses. Considere o contexto em negação por substituição: o texto entrincheira um direito, comanda uma ação ou proíbe alguma conduta particular mas atores políticos, no entanto, negam esse direito, ou recusam seu dever, ou se engajam em uma conduta expressamente proibida. A substituição de uma regra não escrita por uma escrita enfraquece o verdadeiro propósito do texto em que nós 
entendemos como sua função de estabelecer regras de conduta e expectativas que deveriam refletir a realidade ou aspirar a ela.

Não é claro como uma questão abstrata se entre a incorporação por refinamento ou negação por criação de vazio qual dessas estaria em menor consonância com os valores democráticos do estado de direito. A partir da incorporação por refinamento, o costume constitucional refina textualmente um padrão entrincheirado de conduta que não se encontra em lugar algum numa constituição textual. No caso de substancial consentimento de um costume provinciano para formalmente emendar questões federais e provincianas no Canadá, os atores políticos vinculados por padrões refinados estavam alertas da mudança. Mas muitos com a intenção de entender o processo de emenda não encontram o costume no texto constitucional. Tal como a incorporação por preenchimento de vazio, incorporação por refinamento está em menos consonância com os valores de transparência, prestação de contas e previsibilidade do estado de direito que nós associamos em Constituições com grandes textos. A prática política que refina a regra textual não é anunciada no texto, e isso complica o dever de ater os atores políticos a esse padrão.

No entanto, refinamento também deve ser visto longe de ser problemático ao estado de direito. A partir do refinamento, o costume acrescenta novo conteúdo associado para uma regra já entrincheira e conhecida. No que diz respeito ao de substancial consentimento de um costume provinciano, era sabido que a partir do texto constitucional o processo de reforma requeria acordo tanto dos atores provincianos para o caso de emenda provinciana ou de atores federais no caso de emenda federal. Mas o costume provinciano do consentimento substancial introduziu uma regra ao processo de emenda de questões federais-provincianas e, consequentemente, às regras de interação entre atores federais e políticos. O processo era totalmente interno aos atores políticos, em que pese seus efeitos, é claro, iam muito além deles. Ainda, a teoria subjacente à estrutura fundamental e à sequência do processo de emendas nas questões federaisprovincianas eram tanto intuitivas quanto constitucionalmente apropriadas: se uma emenda irá afetar toda a nação, isto é, tanto em nível federal de governo quanto provinciano, faz sentido que os atores políticos envolvidos em sancionar a emenda representem os dois níveis de governo.

O caso de negação por criação de vazio pode, da mesma forma, ser tolerável ou não a depender da natureza do texto constitucional afetado - e claro ele poderia ser em alguns casos tão intolerável para o estado de direito quanto Negação por substituição. Em todos os casos por criação de um vazio, a referência textual permanece mas ela passa a

Revista Publicum 
ser ineficaz como questão de costume. Mas um tipo de vazio é mais sério que outros: a existência de um vazio no texto é menos problemática onde o texto afetado confere sobre o ator político um poder não oficial que efetivamente prescreveu como resultado de seu não-uso $e$ onde nenhuma alternativa viável emerge para preencher seu papel do que um costume que desabilitou um poder oficial cujo propósito foi funcionalmente substituído por outro poder que agora é comumente usado no curso ordinário da prática política. Esse cria um vazio no texto mas também produz um remédio para preencher um hiato funcional no texto.

Por exemplo, o procedimento de convenção nacional de reforma nos Estados Unidos previsto a partir do Artigo $\mathrm{V}$ nunca foi utilizado de maneira bem-sucedida desde a adoção da Constituição ${ }^{155}$. O procedimento autoriza dois terços dos estados peticionarem ao Congresso para instaurar uma convenção e três quartos dos estados para ratificarem as propostas decorrentes da convenção ${ }^{156}$. Alguém poderia sugerir de maneira plausível que a provisão se esgotou como resultado do seu não-uso ${ }^{157}$. Ainda, a prevalência histórica do procedimento iniciado no Congresso para formalmente emendar a Constituição - que foi usada 27 vezes até agora - sugeriria que o propósito da convenção nacional permanecesse alcançável por outros meios ${ }^{158}$. A existência de um análogo funcional não evidenciaria os valores formais e expressos de emendar a Constituição através do processo convencional popularmente legítimo mas a questão é que um procedimento alternativo substituiu um procedimento de convenção nacional.

O vazio criado no procedimento de convenção nacional nos Estados Unidos seria menos problemático que o vazio que foi indiscutivelmente criado no poder legislativo de reversão $^{159}$ no Canadá ${ }^{160}$. A reversão legislativa, entrincheirada na Carta de Direitos $e$ Liberdades, autoriza o Parlamento ou uma legislatura provinciana suspender a interpretação judicial de certos direitos constitucionais por termos de renovação ilimitadas até cinco anos cada ${ }^{161}$.

${ }^{155}$ Ver William B. Fisch, 'Constitutional Referendum in the United States of America' (2006) 54 Am J Comp L, v. 54, 2006. p. 485-490.

156 Constituição dos Estados Unidos, art. V.

157 Ver Akhil Reed Amar, 'The Consent of the Governed: Constitutional Amendment Outside Article V' (1994) 94 Colum L Ver, v. 94, 1994. p. 457, 499 n.164.

158 Alguém pode argumentar também que emendas formais genericamente tem sido funcionalmente mudadas por informais. Ver Stephen M. Griffin, 'The Nominee is ... Article V'. Const Comment, v. 12, 1995. p. 171-172.

159 NT: Legislative Override.

160 Ver Richard Albert, 'Advisory Review: The Reincarnation of the Notwithstanding Clause'. Alberta $L$ Ver, v. 45, 2008. p. 1037, 1041-43.

161 Canadian Charter of Freedoms, seção 33(3)-(4), Parte I do Constitution Act, 1982, sendo Schedule B no Canada Act 1982, 1982, c 11 (UK).

Revista Publicum

Rio de Janeiro, v.2, n. 2, 2016, p. 9-44

http://www.e-publicacoes.uerj.br/index.php/publicum

DOI: 10.12957/publicum.2016.27017 
Parlamento ou a legislatura da província pode expressamente declarar em uma Lei do Parlamento ou da legislatura, conforme o caso, que a Lei ou uma provisão sobre isso deve operar não obstante uma provisão incluída na seção 2 ou seções 7 até 15 dessa Carta. ${ }^{162}$

Acadêmicos sugeriram que essa reversão legislativa se tornou obsoleta e atores políticos no mais alto nível repudiavam-na ${ }^{163}$. A obsolescência da reversão legislativa acoplada com a abstenção de qualquer análogo funcional provaria ser mais problemática para o estado de direito do que a reversão legislativa teria se tornado obsoleta, porém tivesse encontrar algum outro caminho de cumprir sua função. Se a reversão legislativa realmente se esgotasse e perdesse sua viabilidade política, isso deveria ser repelido porque seu presente entrincheiramento textual deforma o verdadeiro conteúdo da constituição atual.

\section{Conclusão}

Tendo posicionado e avaliado quatro formas de mudança constitucional informal por costume constitucional, talvez persista dúvida se existe uma distinção útil entre elas. Talvez, alguém diria, é melhor conceber apenas duas formas de mudança constitucional informal por costume: adição e subtração. Ou talvez nós devamos falar de uma única forma de tal mudança: mudança por costume, se conceitualmente ela acrescenta ou subtrai a partir do texto.

O argumento que sustenta existir uma única abrangente categoria de mudança constitucional informal por costume - mudança por costume em si - se processaria como se segue. Onde uma prática se amadurece em costume constitucional e vincula atores políticos, o novo costume deve necessariamente substituir o entendimento existente sobre o tema com relação ao entendimento existente substituído. Por exemplo, como o caso de incorporação por preenchimento de vazio, o argumento seria que o costume dos dois mandatos presidenciais substituiu o entendimento contemporâneo que não existia limite para elegibilidade e reeleição. Por essa visão, seria incorreto admitir que existiu um

162 Ibid seção 33(1).

163 Ver, eg James Allan, 'Critical Notice: An Unashamed Majoritarian'. Dalhousie LJ, v. 27, 2004. p. 537-547; Jeffrey Goldsworthy, 'Judicial Review, Legislative Override, and Democracy'. Wake Forest $L$ Ver, v. 38, 2003. p. 451, 466-70; House of Commons, Debates, 6 Abr 1989, at 153 (Brian Mulroney); 'Martin Wraps Campaign in Constitutional Pledge', CBC News (10 January 2006) <http://www.cbc.ca/news/canada/martin-wraps-campaign-in-constitutionalpledge- 1.609744> acessado 1 Jun 2015. 
vazio no texto sobre elegibilidade e reeleição. Seria sustentado, de outro modo, que o Poder Constituinte escolheu intencionalmente em deixar fora do texto qualquer menção aos limites porque eles não tinham a intenção de fazê-lo.

Da mesma forma, o costume do consentimento substancial provinciano, que eu apontei como um exemplo de incorporação por refinamento, poderia, ao contrário, ser construído como um exemplo de um novo entendimento substituindo um antigo, não o refinando. Por esse modo, o processo de emenda no Canadá teria sido transformado de um processo com três regras - uma para as Constituições provincianas, uma para as Constituições federais e outra para questões federais-provincianas que apenas o Parlamento do Reino Unido poderia operacionalizar - para uma regra que contemple essas três regras. O novo processo de emenda com três regras seria entendido não apenas como mudança de poder de reforma em questões federais-provincianas passassem do Parlamento do Reino Unido para atores canadenses federais e provincianos, mas também mudar o escopo dos poderes de reforma unilateral, tanto provincianos quanto federais, reduzindo em alguns casos e expandindo em outros, mas em qualquer caso mudando toda a estrutura da emenda. Alguém poderia, consequentemente, entender essa transformação como resultado de uma mudança abrangente para o processo de reforma mais do que um refinamento estreito a isso.

A mesma questão pode ser suscitada no que diz respeito à negação por criação de vazio: a mudança pode ser entendida como modificando um entendimento existente da constituição textual por um novo. Na negação por criação de vazio, especificamente quanto aos poderes de desautorização e reserva no Canadá, a assertiva seria que o desuso de ambos os poderes não teria criado um vazio no texto, mas ao invés teriam criado um costume de não-uso. Existiria, por essa visão, nenhum silêncio resultante na regra de desautorização ou reserva, mas seria um completo novo costume de que nenhum desses poderes deve ser usado à luz do atual entendimento acerca da distribuição de poderes. Alguém poderia argumentar que embora a interpretação prevalente na provisão constitucional existente teria sido repudiada, uma nova interpretação do texto existente teria se enraizado a dar um novo significado ao texto constitucional cujo significado antigo teria sido abandonado.

Essa perspectiva nos levaria a uma conclusão: todos os casos de mudança informal por costume constitucional são ilustrações de negação por substituição. Nessa visão, em todo caso - seja o costume de dois mandatos presidenciais, seja o entrincheiramento do costume do consentimento substancial provinciano, seja o desuso dos poderes de desautorização e reserva, seja o novo significado das Cláusulas de Contrato ou Tratados - 
o entendimento prevalente da Constituição se modificou por um novo, agora interpretação dominante da Constituição, e que rege a conduta dos atores políticos e expectativas públicas até que esse entendimento seja ele mesmo modificado por um novo. Existiria nenhuma distinção entre as quatro formas de mudança constitucional informal porque, em seu núcleo, cada um deles seria entendido como reflexo da criação de um novo costume.

A perspectiva alternativa traz tanto vantagens quanto desvantagens. Considere dois desses benefícios salutares da mudança do entendimento constitucional. Primeiro, a visão de que existe apenas uma categoria de mudança constitucional informal - negação por substituição - poderia ter sido reflexo do que realmente está acontecendo quando um novo costume constitucional se torna formalmente entrincheirado na cultura constitucional: a criação de um novo costume necessariamente implica a rejeição do antigo. Segundo, isso simplifica nossa taxonomia - a taxonomia que, como eu sugeri, é sujeita à crítica que suas linhas divisórias talvez não sejam tal claras como elas primeiro pareceram.

Entretanto, tratando mudança constitucional informal como uma categoria abrangente omite sobre as distinções importantes entre as quatro formas com relação a conformidade às expectativas dos valores democráticos do estado de direito. A esse respeito, as quatro formas de mudança constitucional informal não são as mesmas. Algumas são menos objetáveis que outras e isso é utilmente demonstrado ao isolar a diferença entre elas. Conceituar essas distinções é possível apenas se nós reduzimos a ampla categoria abrangente - mudança constitucional informal - para essas quatro formas subsidiárias. É então que nós talvez contrastamos as quatro formas de mudança constitucional informal por costume constitucional pela conformidade com os valores democráticos do estado de direito. Claro, nós talvez discordemos sobre se um exemplo particular melhor ilustra essa ou aquela mudança constitucional informal. Mas daí esse desafio passa a ser identificar exemplos que ilustrem cada categoria. Usando essas quatro formas de mudança constitucional informal por costume constitucional como nosso ponto de partida talvez leve a mais de quatro, ou claro, menos de quatro, formas. Elas são, no entanto, úteis em si mesmas como ponto de partida em como avaliar os vários caminhos em que normas constitucionais não escritas podem mudar constituições textuais.

Mas questões ainda persistem. Nós deveríamos atribuir com a mesma importância que eu atribuo aos valores democráticos do estado de direito? Talvez isso é menos importante que uma ordem constitucional respeita os valores de transparência, prestação de contas e previsibilidade que isso alcance estabilidade política e social. E onde uma

Revista Publicum 
ordem constitucional é estável, como no Canadá e nos Estados Unidos, deveria isso ser questão o fato de que o texto nem sempre se alinhe com a prática política? Nós devemos também considerar se o leitor razoável é o correto padrão que o juiz deve identificar como o significado constitucional é concebido. Por um lado, a sacralidade da constituição textual é enraizada na ideia do consentimento do governado e isso aconselha alguma atenção à conexão entre cidadãos e o texto constitucional. De outro, nós talvez devêssemos bem questionar se constituições fora dos Estados Unidos são geralmente percebidas como uma "bíblia política" ou se elas existem mais como instrumento funcionais e menos como símbolos de nacionalidade, que ajudam alcançar objetivos mecanicistas de governo. A relação entre resistência constitucional e costume constitucional também merece atenção: são as disjunções entre texto e prática o preço pago pela longevidade constitucional? Essas e outras questões seguem essa investigação da inter-relação entre textualidade e costumes constitucionais, e o estudo do direito público comparado beneficiaria de mais perspectivas além do Canadá e Estados Unidos. 